\title{
Peran Perserikatan Bangsa-Bangsa dalam Kaitannya dengan Penegakan Hukum Oleh Mahkamah Pidana Internasional (Prospek dan Tantangan)
}

\author{
Novy Septiana Damayanti \\ Program Magister Ilmu Hukum Universitas Padjadjaran, Bandung, Indonesia \\ E-mail:novy18002@mail.unpad.ac.id
}

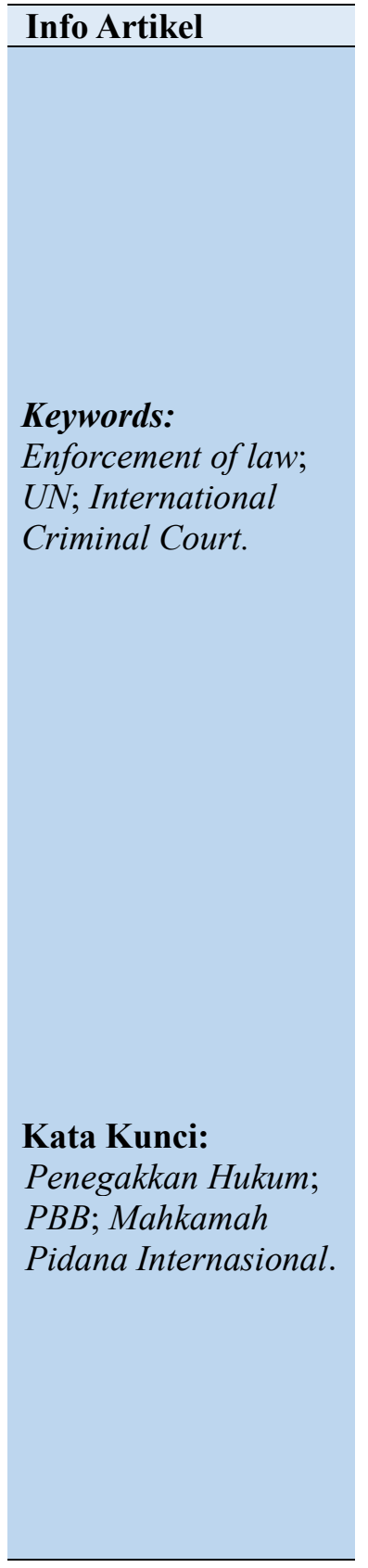

\section{Abstract}

International law in its development moves dynamically according to international community interactions. In the development of international law has spawned an international organization, namely the United Nations (UN). International courts relating to the UN status. The UN has laid the framework of the kosnstitusionic on the underlying instrument of the Charter with the determination of all the members of the UN to avoid the recurrence of World War threats that have twice occurred and have caused A threat to all mankind. THE un-formed International Criminal Court is backed by many demands for justice for its extraordinary crimes (the most serious crime). The International Criminal Court aims to end impunity for perpetrators of gross human rights violations and to give a share of the prevention of the most serious crimes against human rights under international law, as well as Ensure international justice and support the achievement of objectivesof the United Nations Charter principles. Based on the description the problem that will be discussed in this article is the role and authority of THE International Organization $(P B B)$ in maintaining international peace and security in resolving the problems that Conducted by the International Criminal Court (ICC). This Writing uses legal research methods is normative with the research of secondary data and described descriptively.

\begin{tabular}{l}
\hline Abstrak \\
Hukum internasional dalam perkembangannya bergerak secara \\
dinamis sesuai dengan interaksi masyarakat internasional. Dalam \\
perkembangan hukum internasional telah melahirkan suatu \\
organisasi internasional, yaitu Perserikatan Bangsa-Bangsa (PBB). \\
Mahkamah internasional berkaitan dengan status PBB. PBB telah \\
meletakkan kerangka kerja konstitusionalnya pada instrumen pokok \\
yaitu Piagam dengan tekad semua anggota PBB untuk menghindari \\
terulangnya ancaman perang dunia yang pernah dua kali terjadi dan \\
telah menimbulkan ancaman bagi seluruh umat manusia. \\
International Criminal Court yang dibentuk oleh PBB \\
dilatarbelakangi oleh banyaknya tuntutan akan keadilan bagi \\
kejahatan yang luar biasa kejamnya (the most serious crime). \\
Mahkamah Pidana Internasional bertujuan untuk mengakhiri \\
impunitas bagi pelaku pelanggaran berat hak asasi manusia dan \\
memberikan andil bagi pencegahan terjadinya kejahatan paling
\end{tabular}


serius terhadap hak asasi manusia menurut hukum internasional, serta menjamin keadilan internasional dan mendukung pencapaian tujuan dari prinsip Piagam Perserikatan Bangsa-Bangsa. Berdasarkan uraian tersebut permasalahan yang akan dibahas dalam artikel ini adalah peran dan kewenangan organisasi internasional (PBB) dalam menjaga perdamaian dan keamanan internasional dalam menyelesaikan permasalahan yang dilakukan oleh mahkamah pidana internasional (ICC). Penulisan ini menggunakan metode penelitian hukum yuridis normatif dengan penelitian dari data sekunder dan dijelaskan secara deskriptif.

\section{A. PENDAHULUAN}

Organisasi internasional, secara sederhana, dapat didefinisikan sebagai bentuk kerjasama internasional yang melembaga antara negara-negara, umumnya berlandaskan suatu persetujuan untuk melaksanakan fungsi-fungsi yang diberi manfaat timbal balik melalui pertemuan-pertemuan serta kegiatan-kegiatan staf secara berkala. ${ }^{1}$

Jadi, organisasi internasional, menurut pengertian sederhana tersebut mencakup adanya tiga unsur, yaitu: ${ }^{2}$

1) Keterlibatan negara dalam suatu pola kerjasama

2) Adanya pertemuan-pertemuan secara berkala

3) Adanya staf yang bekerja sebagai "pegawai sipil internasional"

Perserikatan Bangsa-Bangsa atau disingkat PBB merupakan sebuah organisasi internasional yang anggotanya hampir seluruh negara di dunia. ${ }^{3}$ PBB merupakan salah satu organisasi internasional dengan anggota mencapai 193 negara hingga saat ini. Keberadaan PBB adalah sebagai suksesor atau pengganti organisasi universal sebelumnya yaitu liga bangsa-bangsa. ${ }^{4}$

Tujuan dari terbentuknya organisasi ini adalah untuk memelihara perdamaian dan keamanan internasional, mengembangkan hubungan persahabatan antar bangsa-bangsa, mengadakan kerjasama internasional guna memecahkan persoalan-persoalan internasional di bidang ekonomi, sosial, kebudayaan atau yang bersifat kemanusiaan, dan menjadi pusat bagi penyelarasan segala tindakan seluruh bangsa dalam mencapai tujuan bersama. $^{5}$

International Criminal Court" (ICC), termasuk hukum Internasional di sini merujuk pada suatu realitas "lembaga hukum" yang bersifat permanen dan mandiri berbentuk pengadilan atau mahkamah pidana. Digagas dan dibentuk oleh PBB, dan oleh Statuta Roma (1998) tentang Pembentukan ICC diberikan kewenangan untuk menyelidiki, mengadili, dan memidana individu tanpa memandang official capacity' yang dimiliki oleh individu tersebut di dalam negara nasionalnya. ${ }^{6}$

Perjuangan untuk membentuk Pengadilan Pidana Internasional (International Criminal Court/ICC) telah dimulai 50 tahun yang lalu untuk mengadili pelanggaran HAM berat seperti "genocide". Hal ini nampak dari Resolusi Majelis Umum PBB No.

1 Rudy, T. M. (2011). Hukum Internasional 2. Bandung: Refika Aditama, h. 93

2 Ibid.

3 Widodo. (2017). Hukum Internasional Publik. Yogyakarta: Aswaja Pressindo, h. 233

4 Sefriani, (2016). Peran Hukum Internasional Dalam Hubungan Internasional Kontemporer. Jakarta: Rajawali Pers, h. 200

5 Pasal 1 Piagam PBB

6 Gunakaya, W. (2013). "Peranan Dan Prospek "International Criminal Court" Sebagai International Criminal Policy Dalam Menanggulangi "Internasional Crimes ". Jurnal Wawasan Hukum, 29 (2), h. 2 
260 tanggal 9 Desember 1948, yang mengadopsi "Convention on the Prevention and Punishment of the Crime of Genocide". ${ }^{7}$ Dimana ditekankan betapa pentingnya kerjasama internasional untuk membebaskan manusia dari perbuatan-perbuatan kejam dan menyebabkan penderitaan yang luar biasa bagi kemanusiaan. ${ }^{8}$ Kerjasama internasional di sini berkaitan dengan usul tentang kemungkinan adanya "international penal tribunal" atau "international judicial organ" dan untuk itu ditugaskan kepada "the International Law Commission" (lLC) untuk mengkajinya.

Kemudian telah terbentuklah apa yang telah dinamakan "the ad hoc International Criminal Tribunal for the Former Yugoslavia" untuk mengadili para pelanggar ham. Dalam sejarah kita telah menyaksikan adanya Pengadilan yang dibentuk setelah Perang Dunia II untuk pengadilan penjahat perang. Pengadilan tersebut adalah pengadilan Nuremberg dan pengadilan Tokyo. Pengadilan Neuremberg dibentuk adanya perjanjian antara sekutu tanggal 8 agustus 1945 dan Pengadilan Tokyo dibentuk tanggal 19 januari 1946. Setelah itu pada peristiwa di bekas negara Yugoslavia dibentuk International Criminal Tribunal for the former Yugoslavia ICTY yang dibentuk berdasarkan Resolusi Dewan Keamanan No. 827 tahun 1991. Kemudian pada tahun 1994 Dewan Keamanan dengan Resolusi No.995 telah membentuk International Tribunal for Rwanda ICTR. ICTY dan ICTR dibentuk sebagai pengadilan ad-hoc. Pengadilan ad-hoc ini mempunyai mandat yang terbatas waktu dan wilayahnya. ${ }^{9}$

Tidak lama setelah itu ILC telah menyelesaikan Rancangan Statuta ICC dan pada tahun 1994 Rancangan ini disampaikan kepada Majelis Umum PBB. Majelis kemudian membentuk Komite ad hoc untuk pembentukan ICC yang mengadakan rapat dua kali pada tahun 1995. Selanjutnya Majelis Umum membentuk Komite Persiapan "consolidated draft text" dalam rangka konperensi diplomatik. Komite persiapan ini bertemu mulai tahun 1996-1998, Yurisdiksi dan Admissibility Pengadilan Pidana lnternasional pada sidang terakhir bulan Maret dan April 1998 teks Rancangan berhasil disempurnakan. ${ }^{10}$

Yurisdiksi kewenangan dari ICC sebagaimana diatur dalam Pasal 5 Statuta Roma 1998, adalah sebagai berikut: ${ }^{11}$

a) Kejahatan genosida (The crime of genocide)

b) Kejahatan kemanusiaan (Crimes against humanity)

c) Kejahatan perang (War crime)

d) Kejahatan agresi (The crime of aggression).

Dalam pasal 126 Statuta Roma menyebutkan bahwa untuk dapat berlaku, perlu diratifikasi oleh sekurang-kurangnya 60 negara. Pada 1 Juli 2002 ketentuan pasal itu terpenuhi kemudian pada Februari sampai Juni 2003 telah ditetapkan hakim, penuntut umum, dan ketua panitra. ${ }^{12}$ Mulai sejak itu ICC dapat melakukan kegiatan operasional sebagaimana mestinya. Dengan ini menegaskan bahwa ICC memiliki norma hukum positif yang sesungguhnya bukan hanya sekedar norma moral (positive morality) yang

7 Muladi. (2001). "Yurisdiksi Dan "Adminissbility" Pengadilan Pidana Internasional". Hukum dan Pembangunan, (4), h. 2

${ }^{8}$ Ibid.

9 Suwardi, S. S. (2003). "Beberapa Catatan Mahkamah Pidana Internasional (International Criminal Court) Dalam Kaitannya Dengan Perserikatan Bangsa- Bangsa (PBB)". Hukum dan Pembangunan, 33 (4), h. 2

10 Muladi, Op. Cit., h. 2

11 Pasal 5 Statuta Roma

12 Diantha, I. M. P. (2014). Hukum Pidana Internasional Dalam Dinamika Pengadilan Pidana Internasional. Jakarta: Kencana Prenada Media Group, h. 66 
diharapkan dapat mengikat negara-negara dalam melakukan tugas, fungsi dan kewenangan sesuai dengan tujuan pembentukan pengadilan ini. ${ }^{13}$

Akan tetapi terdapat perbedaan dalam prakteknya, ICC masih terhambat dalam pelaksanaan kewenangannya oleh karena beberapa ketentuan, antara lain: Pertama, masalah hak veto 5 negara (Amerika Serikat, Prancis, Inggris, Federasi Rusia, Cina) ${ }^{14}$ hal ini didasarkan dalam Statuta Roma pada Pasal 16 dicantumkan ketentuan yang memungkinkan Dewan Keamanan turut campur dalam proses penyelidikan dan penuntutan pelanggaran HAM berat.

Contoh penggunaan hak veto ini adalah dalam kasus presiden Sudan yang kemudian terhambat dalam penuntutan padahal diduga telah melakukan kejahatan berat. Amerika Serikat juga dengan hak vetonya menuntut agar pasukan Amerika yang bertugas dalam operasi pasukan penjaga perdamaian diberi kekebalan (immunity) dari yurisdiksi ICC dengan mengancam memutuskan keterlibatannya dalam pasukan penjaga perdamaian PBB di Bosnia pada 31 Juli 2002 jika hak vetonya tidak diindahkan. Setelah melalui perundingan akhirnya permintaan Amerika dikabulkan dan berhasil mendapatkan penangguhan penyelidikan dan penuntutan dari ICC selama 1 tahun 11 bulan atau sampai operasi penjaga perdamaian selesai. ${ }^{15}$

Mahkamah Pidana Internasional merupakan pengadilan yang permanen (Pasal 3(1) Statuta Roma). Mahkamah Pidana Internasional merupakan mahkamah yang independen dan bukan merupakan badan dari PBB karena dibentuk berdasarkan perjanjian multilateral, meskipun dalam beberapa kondisi tertentu ada relasi peran antara Mahkamah dengan PBB (Pasal 2 Statuta Roma). ${ }^{16}$

Perihal dengan penegakkan perdamaian dan keamanan internasional, PBB melalui Dewan Keamanan mempunyai kewenangan dalam hal melakukan penegakkan hukum terhadap kejahatan tindak pidana internasional. Berdasarkan Pasal 13 poin b Statuta Roma, Dewan Keamanan mempunyai referral jurisdiction untuk mengadili orang yang melakukan tindak pidana internasional. ${ }^{17}$ Dan juga terdapat deferral jurisdiction Pasal 16 Statuta Roma yang diberikan kewenangan untuk turut serta dalam penegakkan berdasarkan Bab VII Piagam PBB.

Dalam kaitannya dengan ICC, meskipun ICC adalah lembaga yang independen, tidak berada di bawah struktur PBB, namun preambul Statuta Roma 1998 mengakui keberadaan PBB. Preambul menegaskan bahwa pembentukan ICC tidaklah bertentangan dengan Piagam PBB. Peran PBB dalam menjaga perdamaian dan keamanan internasional sangat diperlukan dan dewan keamanan dalam menyelesaikan penegakkan oleh mahkamah pidana internasional/ICC agar tidak terjadinya disefeksi maupun ambiguitas terhadap penyelesaian kasus tindak pidana internasional sesuai yang diuraikan dalam Pasal 5 Statuta Roma.

Dalam penulisan terdapat dua rumusan masalah, yaitu: (1) Bagaimana peran dan kewenangan organisasi internasional (PBB) dalam penegakkan hukum oleh mahkamah pidana internasional?; (2) Bagaimana prospek dan tantangan mahkamah pidana internasional (ICC) dalam menyelesaikan kasus the most serious crime?. Adapun dalam

13 Olivia, Op. Cit., h. 2

14 Atmasasmita, R. Op. Cit., h. 66

15 Olivia, Loc. Cit.

16 Katiandagho, K. (2016). "Kewenangan Mahkamah Pidana Internasional Untuk Mengadili Pelaku Kejahatanpelanggaran Ham Berat Dalam Suatu Negara Tanpa Adanya Permintaan Dari Negara Tuan Rumah". Jurnal Ilmiah, h. 5

17 Pasal 13 Poin (b) Piagam PBB 
penulisan ini menggunakan metode penelitian hukum yuridis normatif dengan penelitian dari data sekunder dan dijelaskan secara deskriptif.

\section{B. PEMBAHASAN}

\section{Peran Dan Kewenangan Organisasi Internasional (PBB) Dalam Penegakkan Hukum Oleh Mahkamah Pidana Internasional}

Tidak bisa dipungkiri peran PBB sebagai organisasi internasional dengan anggota terbesar saat ini dalam hubungan internasional kontemporer sangatlah signifikan. PBB adalah organisasi universal dengan kompetisi umum. ${ }^{18}$ PBB dalam menjalankan fungsi pemeliharaan perdamaian keamanan melalui salah satu organ PBB, yaitu Dewan Keamanan (Security Council). Peran Dewan Keamanan dalam Piagam PBB Bab VII tentang Action with Respect to threats, to the Peace, Breaches of the Peace, and Acts of Agression adalah untuk menciptakan perdamaian dan keamanan dunia. Dewan Keamanan ini pada masa awal dibentuknya PBB merupakan satu-satunya badan yang berwenang menegakkan keadilan dan menjaga kemananan internasional.

Menurut Neha Jain bahwa pembentukan dan pemberian kewenangan Dewan Keamanan oleh Piagam PBB sebagai organ yang satu-satunya berwenang menegakkan keadilan dan menjaga keamanan internasional yang mempunyai sifat politis dalam mencapai tujuannya. ${ }^{19}$

Mahkamah Pidana Internasional dan Dewan Keamanan PBB, hubungan keduanya didasari oleh Preambul Statuta Roma baris ke-9 ${ }^{20}$ serta pada pasal 4 ayat (3) ${ }^{21}$ Negotiated Relationship Agreement between the International Criminal Court and the United Nations yang berlaku sah mengikat pada tanggal 4 Oktober 2004. Dari uraian pasal-pasal tersebut menunjukkan diakuinya hubungan antara Dewan Keamanan dan Mahkamah Pidana Internasional, hubungan tersebut bukan hanya mengakui keberadaan namun juga mengakui wewenang satu dengan lainnya. ${ }^{22}$

Dalam upaya menciptakan perdamaian dan keamanan internasional, PBB memiliki lima tindakan. Tindakan tersebut masing-masing saling berkaitan dan dalam pelaksanaannya memerlukan dukungan dari semua negara anggota PBB untuk dapat terwujud. Keempat kelompok tindakan tersebut adalah Preventive Diplomacy, Peace Making, Peace Keeping, Peace Building, Peace Enforcement. ${ }^{23}$

Preambul ke $7^{24}$ dari paragraf statuta roma telah ditegaskan kembali perlunya suatu

18 Sefriani, Peranan Hukum.. Op. Cit., h. 202

19 Jain, N. (2005). “A Separate Law For Peacekeepers: The Clash Between The Security Council And The International Criminal Court”. The European Journal Of International Law, 16 (2), h. 239

20 Preambule 9 Statuta Rome 1998: "Determined to these ends and for the sake of present and future generations, to establish an independent permanent International Criminal Court in relationship with the United Nations system, with jurisdiction over the most serious crimes of concern to the international community as a whole".

21 Article 4 (3) Negotiated Relationship Agreement between the International Criminal Court and the United Nations: "Whenever the Security Council considers matters related to the activities of the Court, the President of the Court ("the President") or the Prosecutor of the Court ("the Prosecutor") may address the Council, at its invitation, in order to give assistance with regard to matters within the jurisdiction of the Court".

22 Kocar, Y. (2015). "The Relationship Between The International Criminal Court And The United Nations Security Council”. Law \& Justice Review, 6 (11), h. 172

97

23 Adolf, H. (2004). Hukum Penyelesaian Sengketa Internasional. Bandung: Sinar Grafika, h. 95-

24 Preambule 7 Statuta Rome 1998: 
negara untuk menyelesaikan sengketa dengan damai dan larangan menggunakan kekerasan yang mengancam integritas wilayah atau kemerdekaan suatu negara.

Berdasarkan ketentuan tersebut ICC merupakan mahkamah yang permanen, independen dan mempunyai hubungan dengan sistem PBB. Mahkamah yang permanen dan independen didasarkan pada tiga prinsip, yaitu pertanggung jawaban individu (individual accounntability), universal (universality) dan jujur (fainess).

Tujuan pertama dari pendirian ICC adalah memungkinkan adanya suatu mekanisme yang mempunyai yurisdiksi terhadap individu untuk bertanggung jawab terhadap tindakan kejahatan yang telah dilakukan. Prinsip ini berhubungan dengan suatu negara yang tidak dapat melindungi warga negaranya termasuk pimpinannya dalam kaitan dengan kejahatan serius terhadap kemanusiaan yang merupakan yurisdiksi ICC. Prinsip pertama ini menimbulkan prinsip kedua yaitu universalitas. Prinsip kedua ini berarti bahwa yurisdiksi ICC harus diterapkan pada semua individu tanpa memandang tingkat jabatannya, kedudukannya dan kewargenegaraannya. Prinsip ketiga jujur (faimess) ini harus diterapkan persamaan keadilan bagi semua dan ini merupakan standar tertinggi dari proses keadilan." 25

Ketika ICC dibicarakan bagaimana hubungannya dengan PBB timbul beberapa pemikiran: ${ }^{26}$

1) ICC sebagai organ utama PBB;

2) Statuta sebagai perjanjian internasional;

3) ICC sebagai organ tambahan dari Majelis Umum PBB

4) ICC sebagai organ tambahan dari Dewan Keamanan

5) ICC sebagai badan Khusus

Hubungan lainnya antara PBB dan Statuta Roma juga terlihat dari wewenang Dewan Keamanan PBB yang disebut juga dengan istilah hak referral (hak menyerahkan) yang diuraikan dalam Pasal 13 Statuta Roma. ${ }^{27}$ Berdasarkan Pasal 13 poin b statuta roma maka ICC dapat menjalankan kewenangannya terhadap tindak pidana serius Pasal 5 Statuta Roma jika terdapat situasi dimana satu atau lebih tindak pidana telah dilakukan oleh pelaku dan perkaranya telah dilimpahkan kepada jaksa penuntut oleh Dewan Keamanan yang dapat bertindak berdasarkan Bab VII Piagam PBB. Dari uraian Pasal 13 poin b maka jelaslah bahwa Dewan Kemananan PBB mempunyai kewenangan untuk mengiterprestasikan atau mengidentifikasikan apakah tindak pidana yang dilakukan berdasarkan Pasal 5 Statuta Roma melanggar ketentuan dari BAB VII Piagam PBB.

Dewan Kemanan PBB juga memiliki hak deferral (hak menangguhkan) seperti

"Reaffirming the Purposes and Principles of the Charter of the United Nations, and in particular that all States shall refrain from the threat or use of force against the territorial integrity or political independence of any State, or in any other manner inconsistent with the Purposes of the United Nations".

25 Suwardi, S. S. Op. Cit, h. 7

26 Ibid.

27 Article 13 Statuta Roma:

"The Court may exercise its jurisdiction with respect to a crime referred to in article 5 in accordance with the provisions of this Statute if:

(a) A situation in which one or more of such crimes appears to have been committed is referred to the Prosecutor by a State Party in accordance with article 14;

(b) A situation in which one or more of such crimes appears to have been committed is referred to the Prosecutor by the Security Council acting under Chapter VII of the Charter of the United Nations; or

(c) The Prosecutor has initiated an investigation in respect of such a crime in accordance with article 15. “

$$
256 \text { | S A S I Vol. } 26 \text { No.2, April - Juni } 2020
$$


yang dijelaskan dalam Pasal 16 Statuta Roma. ${ }^{28}$ Dari pasal tersebut Statuta Roma/ICC dapat menentukan penyidikan, penyelidikan maupun penuntutan tidak dapat dimulai atau dilaksanakan dalam jangka waktu 12 bulan setelah Dewan Keamanan PBB dalam resolusinya yang dibuat berdasarkan Bab VII Piagam PBB telah menangguhkan penyidikan dan penuntutan. Permintaan tersebut bisa diperbarui berdasarkan oleh Dewan Keamanan PBB dalam situasi yang sama kerena terdapatnya sebuah fakta atau kesaksian yang baru. Dari uraian Pasal 16 Statuta Roma ini jelaslah bahwa Dewan Kemanan PBB mempunyai peran dan wewenang yang sangat besar, tentunya hal tersebut sangat memperngaruhi pelaksanaan dalam penegakkan tindak pidana internasioal oleh ICC.

Keterkaiatan antara hak referral (hak menyerahkan) dan hak deferral (hak menangguhkan) diatas dalam pelaksanaannya juga perlu memperhatikan Pasal 17 Statuta Roma yang mengatur dapat diterimanya sebuah perkara. Walaupun Mahkamah Pidana Internasional sebagai lembaga Hukum Internasional yang tersendiri karena kedudukannya terlepas dari PBB. ${ }^{29}$ Meskipun Mahkamah Pidana Internasional terlepas dari PBB, Mahkamah Pidana Internasional kinerjanya dipengaruhi oleh hubungan yang berkembang dengan Dewan Keamanan PBB. Hubungan ini dijelaskan dalam Preambul Statuta Roma serta pada pasal 4 ayat (3) Negotiated Relationship Agreement between the International Criminal Court and the United Nations. Selanjutnya hubungan tersebut dituangkan lebih lanjut pada pasal 13 dan pasal 16 Statuta Roma mengenai kewenangan Dewan Keamanan dalam yurisdiksi Mahkamah Pidana Internasional.

Peristiwa demikian dicontohkan dengan resolusi Dewan Keamanan 1422 pada tahun 2002. Resolusi tersebut mengacu pada pasal 16 Statuta Roma. Amerika Serikat mengancam akan menarik pasukan penjaga perdamaian Perserikatan Bangsa-Bangsa di Bosnia apabila tidak diberikan kekebalan hukum atas yurisdiksi Mahkamah Pidana Internasional terhadap pasukan-pasukan tersebut. ${ }^{30}$ Resolusi 1422 akhirnya diadopsi mengikuti permintaan tersebut pada tahun 2002. Moss kemudian menyatakan dalilnya :

a) Resolusi 1422 Dewan Keamanan Perserikatan sebenarnya menyimpang dari ketentuan pasal yang tercantum dalam Pasal 16 Statuta Roma.

b) Ketentuan pasal 16 Statuta Roma, bahwa Statuta Roma mengamanatkan penangguhan proses penyelidikan atau penuntutan perkara, bukan memberi kekebalan hukum, dengan demikian Amerika Serikat menyimpang dari Statuta Roma.

c) Bahwa dalam keanggotan permanen Dewan Keamanan, hanya Inggris dan Perancis menjadi anggota dari Statuta Roma.

d) Amerika Serikat bukan pihak dari Statuta Roma, namun dengan kekuatannya sebagai Dewan Keamanan Perserikatan Bangsa-Bangsa bersama empat anggota

28 Article 16 Statuta Roma:

"No investigation or prosecution may be commenced or proceeded with under this Statute for a period of 12 months after the Security Council, in a resolution adopted under Chapter VII of the Charter of the United Nations, has requested the Court to that effect; that request may be renewed by the Council under the same conditions."

29 Obura, K. (2015). The Security Council And The International Criminal Court: When Can The Security Council Defer A Case?. Strathmore Law Journal, h. 122., baca juga Article 4 Statuta Roma, The Court shall have international legal personality. It shall also have such legal capacity as may be necessary for the exercise of its functions and the fulfilment of its purposes. The Court may exercise its functions and powers, as provided in this Statute, on the territory of any State Party and, by special agreement, on the territory of any other State.

30 Anditya, A. W. (2017). Implikasi Hak Referral Dan Hak Deferral Dewan Keamanan Perserikatan Bangsa-Bangsa Terhadap Penegakan Hukum Pidana Internasional Oleh Mahkamah Pidana Internasional, Tesis, Universitas Gadjah Mada, h. 13 
permanen lainnya, dapat mempengaruhi kepercayaan dunia terhadap Mahkamah Pidana Internasional.

Dewan Keamanan adalah badan yang terlepas dari Statuta Roma diberikan hak untuk menyerahkan keadaan (referral) dan hak untuk menangguhkan proses penyelidikan atau penuntutan (deferral) oleh Statuta Roma, Dewan Keamanan harus menghormati independensi dan yurisdiksi Mahkamah Pidana Internasional. Hak-hak Dewan Keamanan tersebut hanya dapat diterapkan atas dasar keadaan yang benar-benar mengancam perdamaian serta keamanan dunia. Hal ini dapat ditinjau dari pasal 17, pasal 18, dan pasal 19 Statuta Roma, bahwa Mahkamah Pidana Internasional memiliki hak untuk tetap objektif dan tunduk pada pasal 53 Statuta Roma dalam menerima atau menangguhkan proses penyelidikan atau penuntututan. ${ }^{31}$

Hak veto dari Dewan Keamanan PBB yang membatasi yurisdiksi ICC dimana Hak veto dimiliki oleh 5 anggota tetap Dewan Keamanan PBB, yakni Amerika Serikat, Inggris, Rusia, Cina, dan Prancis. Hak veto adalah hak untuk membatalkan keputusan, ketetapan, rancangan peraturan dan undang-undang atau resolusi. Penggunaan Hak veto ini didasarkan dalam Statuta Roma Pasal 16 Statuta Roma.

Berdasarkan pasal ini, maka Dewan Keamanan dimungkinkan untuk turut campur dalam proses penyelidikan dan penuntutan pelanggaran HAM berat. Berikut ini beberapa contoh penggunaan Hak veto dalam yurisdiksi ICC yang menimbulkan kontroversi, antara lain: ${ }^{32}$

Pertama, dalam kasus kejahatan kemanusiaan yang melibatkan presiden Sudan. Dalam pelaksanaan kewenangan ICC sehubungan dengan kasus ini, Amerika Serikat menggunakan Hak vetonya untuk mendapat penangguhan penuntutan presiden Sudan karena ketentuan Pasal 16 Statuta Roma. ICC pun menangguhkan penuntutan terhadap presiden Sudan.

Kedua, penggunaan Hak veto oleh Amerika Serikat yang menuntut agar pasukan Amerika yang bertugas dalam operasi pasukan penjaga perdamaian diberi kekebalan (immunity) dari yurisdiksi ICC dengan mengancam memutuskan keterlibatannya dalam pasukan penjaga perdamaian PBB di Bosnia pada 31 Juli 2002 jika hak vetonya tidak diindahkan. Setelah melalui perundingan akhirnya permintaan Amerika dikabulkan dan berhasil mendapatkan penangguhan penyelidikan dan penuntutan dari ICC selama 1 tahun 11 bulan atau sampai operasi penjaga perdamaian selesai.

Ketiga, penggunaan Hak veto oleh Amerika untuk Israel atas kasus kejahatan internasional yang dilakukan oleh Israel. Penggunaan Hak veto Amerika Serikat untuk membela Israel adalah sebanyak 39 veto, padahal Israel telah melakukan banyak pelanggaran terhadap beberapa resolusi PBB, antara lain resolusi 271, 298, 452, dan 673.

Contoh penggunaan Hak veto diatas menunjukan bahwa anggota tetap Dewan Keamanan dalam menggunakan Hak vetonya mengacu pada national interest atau kepentingan negara itu sendiri. Penggunaan hak veto ini bertentangan dengan asas keadilan dan mengingkari realitas sosial. PBB diharapkan dapat merevisi kembali penggunaan Hak veto oleh Dewan Keamanan. Hal ini dikarenakan bahwa Hak veto tidak sesuai dengan prinsip persamaan kedudukan negara. Christian Wolff mengemukakan bahwa antara satu negara dengan negara yang lainnya memiliki kedudukan yang sama satu sama lain. ${ }^{33}$ Walaupun negara-negara Dewan Keamanan anggota tetap seperti

31 Ibid., h. 14

32 Olivia, Op. Cit., h. 5

33 Adolf, H. (2015). Aspek-Aspek Negara Dalam Hukum Internasional. Bandung: Keni Media, h. 
Amerika Serikat dan lainnya memiliki hak untuk turut serta dalam kasus yang diadili oleh ICC akan tetapi hal tersebut dalam hukum internasional terjadi pertentangan norma seperti halnya dengan prinsip persamaan kedudukan negara.

Masalah lain yang membayang-bayangi legitimasi ICC, selain penggunaan Hak veto ialah ketentuan dalam Pasal 98 Statuta Roma Merujuk pada ketentuan Pasal 98 Statuta Roma di atas, menunjukkan bahwa efektivitas ICC dalam menuntut dan mengadili pelaku kejahatan HAM berat masih terhambat oleh ketentuan tersebut di atas. Hal ini terbukti dari kenyataan praktik implementasi Statuta ICC, dimana Amerika Serikat telah dapat memanfaatkan celah hukum di atas yaitu dengan mengadakan perjanjian bilateral dengan negara lain untuk tidak menyerahkan kepada ICC. Perjanjian bilateral tersebut disebut United States Bilateral Agreement for Immunity. Perjanjian ini menyatakan bahwa tidak ada warga negara, baik pejabat maupun mantan pejabat, atau personil militer setiap pihak yang bisa diserahkan atau dipindahkan oleh negara lain ke ICC untuk tujuan apapun. ${ }^{34}$

\section{Prospek dan Tantangan Mahkamah Pidana Internasional (ICC) Dalam Menyelesaikan Kasus The Most Serious Crime}

Statuta Roma adalah perjanjian yang diadopsi dalam Konferensi Roma 1998 untuk menjadi dasar terbentuknya International Criminal Court (ICC). Perjanjian yang disusun dan disetujui pada hari yang sama yaitu 17 Juli 1998 tersebut hingga saat ini telah diratifikasi oleh 124 negara, sedangkan jumlah negara penandatangan mencapai 139 negara. Terkait ICC, Statuta Roma mengaturnya di bagian 1. Pasal $1^{35}$ Statuta Roma mendefinisikan ICC sebagai "suatu lembaga permanen dan mempunyai kekuasaan untuk melaksanakan jurisdiksinya atas orang-orang untuk kejahatan paling serius yang menjadi perhatian internasional, sebagaimana dicantumkan dalam Statuta ini, dan merupakan pelengkap terhadap jurisdiksi kejahatan nasional". Yakni sehubungan dengan sifat Komplementer dari ICC terhadap pengadilan nasional dan bukan bersifat sub-ordinatif.

Hal ini juga dapat diartikan bahwa sesungguhnya masyarakat internasional menaruh harapan besar akan lebih baiknya penegakkan hukum terhadap pelaku kejahatan internasional dengan kehadiran ICC, Namun demikian ternyata tidak seperti yang diharapkan, kehadiran ICC pada akhirnya mendapat penolakan dari negara Amerika Serikat. Negara yang semula menjadi sponsor ini menjadi khawatir. ${ }^{36}$

Prinsip yang mendasar dari Statuta Roma ini adalah bahwa ICC "merupakan pelengkap bagi yurisdiksi pidana nasional". Ini berarti bahwa Mahkamah harus mendahulukan sistem nasional, kecuali jika sistem nasional yang ada benar-benar tidak mampu (unable) ${ }^{37}$ dan tidak bersedia (unwilling) ${ }^{38}$ untuk melakukan penyelidikan atau

48

34 Shaw, M. N. (2013). Hukum Internasional. Bandung: Nusa Media, h. 402

35 Article 1 Statuta Roma:

"permanent institution and shall have the power to exercise its jurisdiction over persons for the most serious crimes of international concern, as referred to in this Statute, and shall be complementary to national criminal jurisdictions".

36 Sefriani, (2009). "Kewenangan Dewan Keamanan Menghentikan Yurisdiksi ICC : Studi Kasus Resolusi Dewan Keamanan Nomor 1497 Tahun 2003”, Jurnal Hukum 16 (1), h. 3

37 Unable-tidak mampu (Pasal 17 (3)) Pengadilan suatu negara dinyatakan tidak mampu apabila terjadi kegagalan sistem pengadilan nasional, secara menyeluruh ataupun sebagian. Sehingga negara tersebut tidak mampu menghadirkan tertuduh atau bukti dan kesaksian yang dianggap perlu untuk menjalankan proses hukum

${ }^{38}$ Unwilling-tidak bersungguh-sungguh (Pasal 17 (2)) Suatu negara dinyatakan tidak mempunyai 
menuntut tindak kejahatan yang terjadi, maka akan diambil alih menjadi dibawah yurisdiksi Mahkamah berdasarkan Pasal 17 Statuta Roma.

Berkaitan dengan yurisdiksi atau kewenangan mengadili, maka ICC dibatasi oleh beberapa hal: Pertama, berdasarkan subjek hukum yang dapat diadili atau personal jurisdiction (rationae personae), ICC hanya dapat mengadili individu (natural person). Pelaku kejahatan dalam yurisiksi ICC harus mempertanggungjawabkan perbuatannya secara individu (individual responsibility), termasuk pejabat pemerintahan, komandan baik militer muapun sipil. Kedua, berdasarkan jenis kejahatan yang menjadi ruang lingkupnya atau material jurisdiction (rationae materiae). ${ }^{39}$ Maka yurisdiksi ICC adalah pada kejahatan-kejahatan yang merupakan kejahatan paling serius (the most serious crime) dalam pandangan masyarakat internasional yang diatur dalam Pasal 5-8 Statuta Roma 1998.

Adapun pemicu berlakunya yurisdiksi ICC didasarkan pada tiga institusi sebagai triggered jurisdiciton, yakni Complaint by a State Party; Refferal by the Security Council dan Trigger by the Prosecutor. Berkenaan dengan Dewan Keamanan PBB, maka dapat dikemukakan bahwa kewenangan tersebut didasarkan pada Pasal 39 Piagam PBB yang menyatakan bahwa :

"Dewan Keamanan akan menentukan ada tidaknya satu ancaman terhadap perdamaian, pelanggaran terhadap perdamaian, atau tindakan agresi dan akan menganjurkan atau memutuskan tindakan apa yang harus diambil sesuai dengan Pasol 41 dan 42. Untuk memelihara atau memulihkan perdamaian dan keamanan internasional" .

Berdasarkan Pasal 39 Piagam PBB diatas Maupun pasal 13 Statuta Roma, maka terdapat hubungan yang sangat erat antara Dewan Keamanan PBB dengan ICC yang merupakan dua lembaga yang sama-sama bekerja sama dalam memelihara dan menjaga perdamaian dan keamanan internasional namun dalam penyelesaiannya yang berbeda.

Dewan Keamanan PBB berdasar pada Pasal 13b Statuta Roma 1998, di mana di dalam Statuta Roma 1998 yang hanya dapat dijalankan oleh Dewan Keamanan PBB, khususnya oleh anggota tetap. Dalam hal ini yang diperlukan adalah penyerahan resolusi oleh Dewan Keamanan PBB yang berdasar Bab VII Piagam PBB dan berdasarkan resolusi tersebut dan menyerahkan kasus pelanggaran HAM berat kepada ICC.

Terdapat perbedaan mendasar antara pelaksaan yurisdiksi dari ICC oleh Dewan Keamanan PBB dengan negara peserta Statuta atau Jaksa Penuntut ICC yang membuat yurisdiksi ICC menjadi absurd, tidak praktis dan terbatas pada hal-hal tertentu, ini karena disebabkan oleh adanya pra kondisi berlakunya yuridiksi ICC sebagaimana yang diatur dalam Pasal 12. Dimana yurisdiksi dari ICC berlaku terhadap negara peserta dan tempat terjadinya pelanggaran HAM harus merupakan keseluruhan dari negara peserta Statuta Roma. Apabila terdapat negara yang menjadi pihak Statuta Roma setelah Statuta berlaku, maka ICC hanya dapat melaksanakan yurisdsiksi terhadap kejahatan yang dilakukan setelah berlakunya ratifikasi atau aksesi oleh negara tersebut.

kesungguhan dalam menjalankan pengadilan apabila: (1) Pengadilan nasional dijalankan dalam rangka melindungi pelaku dari tanggung jawab pidana atas kejahatan berat tersebut (2) Terjadi penundaan yang tidak konsisten dengan niat untuk mendapat keadilan; (3) Pengadilan dilakukan secara tidak independen dan memihak, serta tidak konsisten dengan niat untuk mendapatkan keadilan

39 Sefriani, (2009). "Kewenangan Dewan Keamanan Menghentikan Yurisdiksi ICC : Studi Kasus Resolusi Dewan Keamanan Nomor 1497 Tahun 2003”. Jurnal Hukum, 16 (1), h. 6 
Prospek dari ICC seharusnya diletakkan pada adanya kemauan dan kerjasama negara-negara di dunia, mengingat penegakkan hukum pidana internasional terhadap pelaku pelanggaran most serious crimes yang lebih diutamakan dibandingkan kejahatan atau tindak pidana yang bisa diselesaikan melalui pengadilan nasional suatu negara. Kerjasama sama antara negara-negara sangat diperlukan oleh ICC dalam rangka penegakkan pelanggaran HAM ketika suatu negara tidak memiliki kemampuan dalam penegakkan kejahatan tersebut.

Dari penjelasan ICC diatas, dimasa yang akan datang ICC akan mengalami berbagai macam hambatan dan tantangan dalam kaitannya terhadap negara, baik yang telah melalui ratifikasi aksesi dan negara yang tidak mau mengikatkan diri pada ICC seperti negara Amerika Serikat, China, Israel dsb. Disamping hal itu akan terjadi juga tantangan sehubungan dengan penerapan yuridiksi dari ICC yang melalui prinsip komplementer yang merupakan bentuk perluasan dari penegakkan pengadilan nasional.

Tantangan lainnya berupa kewenangan dari Dewan Keamanan PBB yang ditimbulkan oleh implikasi pengaturan ICC secara politis maupun adanya kepentingan politik dari negara negara adidaya ataupun negara yang termasuk dalam anggota tetap yang tidak dinaungi oleh ICC yang pada akhirnya menghambat eksistensi dari ICC. Tantangan berikutnya yakni permasalahan kedaulatan negara dan non intervensi negara lain, yang dengan hal tersebut suatu negara tidak mudah menyerahkan warga negara untuk diadili oleh ICC.

Prinsip dasar yang dianut dalam Statuta Roma adalah bersifat "komplemeter". Artinya, terjadinya kejahatan yang menjadi yurisdiksi Mahkamah Pidana Internasional, maka pengadilan terhadap pelaku terlebih dulu diserahkan kepada hukum nasional negara di mana kejahatan dilakukan. Apabila negara yang bersangkutan tidak mau (unwilling) atau tidak dapat (unable) mengadili pelaku kejahatan tersebut, maka peran Mahkamah Pidana Internasional diperlukan terhadap pelaku pelaku kejahatan tersebut. ${ }^{40}$

Salah satu masalah yang telah sekian lama adalah konflik antara Israel dan Palestina adalah sebuah konflik antara Israel dan Palestina dalam memperebutkan otoritas tanah yang mana kedua belah pihak mengklaim mempunyai hak yang sama atas tanah tersebut. Dalam penelitian ini tanah yang diperebutkan itu disebut Tanah Suci. Perang 6 hari atau Perang Arab-Israel 1967 adalah perang yang berlangsung selama 6 hari ini merupakan konflik bersenjata antara Israel melawan negara-negara Arab yang diwakili oleh Mesir, Suriah dan Yordania. Pasca perang yang dimenangkan oleh Israel tersebut, wilayah Israel terus meluas, sementara wilayah negara-negara Arab mulai berkurang. Kejahatan Perang Israel terhadap Palestina yang menimbulkan kerugian dan banyaknya korban jiwa adapun pelanggaran tersebut diantara-Nya melakukan penyerangan terhadap penduduk sipil, menyerang obyek sipil, fasilitas umum, penggunaan senjata terlarang, penyerangan udara secara tidak proporsional. Akibat dari serangan tersebut mengakibatkan lebih dari Empat puluh warga Palestina telah tewas dan 5.511 terluka dalam pawai Gaza di sepanjang pagar perbatasan antara Jalur Gaza dan Israel sejak 30 Maret 2018. Dari mereka yang berada di rumah sakit pemerintah, 1.499 terkena peluru tajam, 107 dengan peluru bermata spons, 408 menderita inhalasi gas dan 582 menderita luka-luka lainnya; 2.142 adalah orang dewasa dan 454 adalah anak di bawah umur. ${ }^{41}$

Negara yang dianggap melakukan unwilling dan unable pada prinsipnya hanya

${ }^{40}$ Hiariej, E. (2009). Pengantar Hukum Pidana Internasional. Jakarta: Erlangga, h. 72

${ }^{41}$ Matamata Politik. (2018). Luka PBB Laporkan Jumlah Palestina Yang Terus Bertambah Di Pawai Gaza. Retrieved from https://www.matamatapolitik.com/40-mati-5-511-lukaluka-pbb-laporkan-jumlahkorban. 
berlaku bagi negara peserta yang telah melakukan ratifikasi terhadap statuta roma akan tetapi makna bisa diperluas dengan dasar ICC memiliki kewenangan untuk mengadili kejahatan yang paling serius (the most serious crimes). Pada Pasal 12 ayat (2) Statuta Roma dinyatakan bahwa ICC memiliki kewenangan untuk mengadili individu yang melakukan kejahatan di wilayah teritorial negara pihak dari ICC atau individu yang berasal dari negara yang sudah menjadi pihak dari ICC. ${ }^{42}$

Kejahatan perang (war crime) yang dilakukan oleh Israel terhadap Palestina dalam praktiknya kejahatan yang dilakukan termasuk dalam wilayah negara yang menjadi pihak dalam Statuta Roma yakni negara Palestina maka hal tersebut sesuai dengan ketentuan pasal 12 ICC ayat 2, walaupun Israel bukan menjadi pihak dari ICC maka ICC memiliki kewenangan untuk mengadili berdasarkan pasal tersebut walaupun Israel sendiri bukan merupakan non pihak Statuta Roma. ${ }^{43}$

Pada Pasal 34 Vienna Convention on the Law of Treaties (VCLT) 1969 secara tegas diatur bahwa: "A treaty does not create either obligations or rights for a third State without its consent". Pasal ini memperlihatkan hubungan antara negara non pihak ${ }^{44}$ dengan perjanjian internasional adalah dengan adanya consent. Prinsip ini dikenal dengan prinsip pacta tertiis nec nocent nec prosunt yang mengandung makna bahwa suatu perjanjian internasional hanya memberikan hak dan kewajiban terhadap para pihak yang terikat pada perjanjian tersebut. ${ }^{45}$

Israel sendiri selalu beranggapan dan berlindung dari salah satu prinsip dari hukum internasional yakni prinsip pacta tertiis nec nocent nec prosunt yang berarti bahwa Statuta Roma 1998/ICC tidak memiliki kewenangan untuk turut serta dalam mengadili kejahatan perang yang dilakukan oleh Israel. Penulis berpendapat dengan keadaan suatu negara yang dianggap tidak mau (unwilling) atau tidak dapat (unable) seperti dalam kasus Palestina diatas maka dalam hal ini berlakulah prinsip komplemeter dari Statuta Roma 1998 yang merupakan perluasan dari pengadilan nasional yang berarti ICC memiliki kewenangan dalam mengadili kejahatan tersebut seperti halnya Kejahatan perang tersebut termasuk bagian yurisdiksi dari Mahkamah Pidana Internasional yang termasuk dalam ruang lingkup kejahatan Pasal 5 Statuta Roma. Maka kejahatan perang yang dilakukan oleh Israel terhadap Palestina telah menciderai hukum internasional dan telah termasuk dalam yurisdiksi dari mahkamah pidana internasional yakni:

Pertama, tindakan dan perlakuan tentara Israel terhadap Palestina merupakan kejahatan perang (war crimes), yang merupakan yurisdiksi Mahkamah Pidana Internasional berkaitan dengan pokok perkara (subject matter jurisdiction), sebagaimana termasuk dalam kategori pasal 5 ayat (1) Statuta Roma 1998.

Kedua, kejahatan perang yang dilakukan oleh tentara Israel terjadi terus menerus

42 Pasal 12 ayat (2) Statuta Roma menyatakan bahwa: "Dalam hal pasal 13, ayat (a) atau (c), Mahkamah

dapat melaksanakan jurisdiksinya kalau satu atau lebih Negara berikut ini adalah pihak dari Statuta ini atau telah menerima jurisdiksi Mahkamah sesuai dengan ayat 3:

(a) Negara yang berkuasa atas wilayah di mana perbuatan yang dipersoalkan itu terjadi atau, kalau kejahatan itu dilakukan di atas kapal atau pesawat terbang, Negara di mana kapal atau pesawat terbang itu terdaftar;

(b) Negara di mana orang yang dituduh melakukan kejahatan adalah warga negara"

${ }^{43}$ Hadju, Z. A. A. (2019). "Anotasi Spirit Unable Dan Unwilling Terhadap Kejahatan Perang Israel

Palestina". Jambura Law Review, 1 (2), h. 18

44 Pasal 34 VCLT

45 Parthiana, I. W. (2005). Hukum Perjanjian Internasional. Bagian II, Bandung: Mandar Maju, h. 
sampai dengan saat ini, dimana tahun-tahun tersebut merupakan tahun setelah berlakunya Statuta Roma 1998 pada tanggal 1 Juli 2002, yang artinya termasuk dalam yurisdiksi Mahkamah Pidana Internasional berkaitan dengan waktu (Temporal Jurisdiction).

Ketiga, walaupun kejahatan perang dilakukan di wilayah teritorial Israel yang mana bukan merupakan negara yang ikut meratifikasi Statuta Roma 1998, apabila kejahatan yang dilakukan termasuk dalam kategori kejahatan yang termasuk dalam Pasal 5 Statuta, maka berdasarkan prinsip universal yang dikenal dalam Hukum Internasional semua negara termasuk di dalamnya pengadilan internasional memiliki yurisdiksi terhadap pelaku tanpa memperhatikan nasionalitas para pelaku maupun tempat dilakukannya kejahatan tersebut. Dari penjelasan tersebut, maka Mahkamah Pidana Internasional tetap mempunyai yurisdiksi teritorial (territorial jurisdiction).

Sifat permanen ICC untuk semua negara yang menghendaki agar ICC tidak terlalu diberi ruang yang luas bagi munculnya judge-made law, yang oleh beberapa negara bisa dipandang sebagai suatu bentuk ketidakpastian yang bertentangan dengan prinsip nulum crimen sine lege. ${ }^{46}$ Secara keseluruhan, Statuta Roma 1998 memuat daftar lima puluh perbuatan yang dapat dikategorikan sebagai kejahatan perang (war crimes). terdapat norma hukum kebiasaan internasional yang justru tidak dimasukkan ke dalam rumusan Statuta Roma 1998, misalnya norma yang melarang penggunaan senjata biologis dan kimiawi. ${ }^{47}$

Yurisdiski ICC atas warga non state party adalah bahwa Pasal 27 Statuta Roma 1998 Pasal di atas tidak membedakan antara imunitas personal dengan immunity ratione materiae. Sebaliknya Pasal 27 Statuta Roma 1998 merekomendasikan bahwa pejabat negara akan bertanggungjawab terhadap segala tindakan yang dilakukannya atas nama negara, pejabat negara di sini termasuk pejabat yang menikmati personal imunitas. Pasal 28 dimaksudkan untuk menghapuskan praktik impunitas. Secara umum impunitas dipahami sebagai tindakan yang mengabaikan penegakan hukum terhadap pelaku kejahatan atau dalam kepustakaan umum sering kali diartikan sebagai absence of punishment. ${ }^{48}$

Suatu negara dikatakan tidak mempunyai kemauan dalam menyelenggarakan peradilan atas pelaku kejahatan yang terdapat dalam Statuta Roma 1998 apabila peradilan nasional dibentuk untuk melindungi pertanggung jawaban pelaku, ketidakmampuan negara dalam menyelenggarakan peradilan atas pelaku kejahatan yang terdapat dalam Statuta Roma 1998 dapat dilihat apabila tidak mampu untuk membawa pelaku ke hadapan pengadilan, jika tidak mampu untuk mendapatkan bukti-bukti dan kesaksian berhubungan dengan kejahatan tersebut, dan jika tidak berfungsinya sistem hukum nasional baik sebagian atau seluruhnya.

\section{PE N T U P}

Berdasarkan hasil pembahasan dalam penelitian ini. Penulis menyimpulkan beberapa hasil dari penelitian bahwa peran PBB dalam ICC juga dilihat dari wewenang DK PBB yang terdapat istilah hak referral (hak menyerahkan) yang diuraikan dalam Pasal 13 Statuta Roma terhadap kejahatan dalam Pasal 5 Statuta Roma dan hak deferral

46 Nulum Crimen Sine Lege merupakan Suatu perbuatan menjadi tindak pidana yang pelakunya dapat dijatuhi hukuman hanya kalau sebelum perbuatan itu dilakukan dan sudah ada hukum yang menyatakan demikian

47 Siswanto, A. (2015). Hukum Pidana Internasional. Yogyakarta: Andi, h.196

48 Sefriani, Yurisdiksi ICC., Op. Cit., h. 15 
(hak menangguhkan) seperti yang dijelaskan dalam Pasal 16 Statuta Roma yang dapat menentukan penyelidikan maupun penuntutan tidak dapat dimulai atau dilaksanakan dalam waktu 12 bulan berdasarkan BAB VII Piagam PBB. Peristiwa demikian telah dilakukan dalam resolusi DK 1422 tahun 2002 yang mengacu terhadap Pasal 16 Statuta Roma. Amerika Serikat mengancam akan menarik pasukan penjaga perdamaian Perserikatan Bangsa-Bangsa di Bosnia apabila tidak diberikan kekebalan hukum atas yurisdiksi Mahkamah Pidana Internasional terhadap pasukan-pasukan tersebut. DK PBB juga memiliki hak untuk campur tangan dalam proses penyelidikan dan penuntutan kasus yang diadili ICC. Prospek dari ICC diletakkan pada kemauan dan kerjasama negaranegara terhadap pelaku kejahatan paling serius, kerjasama antara negara-negara sangat diperlukan ICC dalam penegakkan pelanggaran HAM, Tantangan yang dihadapi berupa DKK PBB yang ditimbulkan secara politis dan adanya kepentingan politik dari negara anggota tetap DKK yang tidak dinaungi oleh ICC dan terkait dengan non intervensi terhadap negara lain, yang pada akhirnya menghambat eksistensi dari ICC. ICC memiliki empat macam yurisdiksi yakni, yurisdiksi personal, kriminal, temporal dan teritorial. Pasal 17 ayat 2 dan ayat 3 menentukan negara yang dianggap tidak mau (unwilling). ketidaksediaan (unable). Berkenan dengan hal itu kita dapat kembali ke prinsip otomatis yaitu locus delicti bahwa Israel melakukan kejahatan perang di wilayah palestina dan didukung dengan yurisdiksi dari mahkamah tersebut maka ICC sudah lebih dari cukup untuk mengadili Israel dengan menggunakan yurisdiksi prinsip otomatis yang terkandung dalam statute roma 1998.

\section{DAFTAR PUSTAKA}

\section{Buku}

[1] Adolf, H. (2004). Hukum Penyelesaian Sengketa Internasional. Bandung: Sinar Grafika.

[2] Adolf, H. (2015). Aspek-Aspek Negara Dalam Hukum Internasional. Bandung: Keni Media.

[3] Diantha, I. M. P. (2014). Hukum Pidana Internasional Dalam Dinamika Pengadilan Pidana Internasional. Jakarta: Kencana Prenada Media Group.

[4] Hiariej, E. (2009). Pengantar Hukum Pidana Internasional. Jakarta: Erlangga.

[5] Muladi. (2001). "Yurisdiksi Dan "Adminissbility" Pengadilan Pidana Internasional". Hukum dan Pembangunan.

[6] Parthiana, I. W. (2005). Hukum Perjanjian Internasional. Bagian II, Bandung: Mandar Maju.

[7] Rudy, T. M. (2011). Hukum Internasional 2. Bandung: Refika Aditama.

[8] Shaw, M. N. (2013). Hukum Internasional. Bandung: Nusa Media.

[9] Siswanto, A. (2015). Hukum Pidana Internasional. Yogyakarta: Andi.

[10] Sefriani, (2016). Peran Hukum Internasional Dalam Hubungan Internasional Kontemporer. Jakarta: Rajawali Pers.

[11] Widodo. (2017). Hukum Internasional Publik. Yogyakarta: Aswaja Pressindo.

\section{Jurnal}

[12] Gunakaya, W. (2013). "Peranan Dan Prospek "International Criminal Court" Sebagai International Criminal Policy Dalam Menanggulangi "Internasional Crimes ”. Jurnal Wawasan Hukum, 29 (2). 
[13] Hadju, Z. A. A. (2019). “Anotasi Spirit Unable Dan Unwilling Terhadap Kejahatan Perang Israel Palestina". Jambura Law Review, 1 (2).

[14] Jain, N. (2005). "A Separate Law For Peacekeepers: The Clash Between The Security Council And The International Criminal Court". The European Journal of International Law, 16 (2).

[15] Kocar, Y. (2015). "The Relationship Between The International Criminal Court And The United Nations Security Council”. Law \& Justice Review, 6 (11).

[16] Katiandagho, K. (2016). "Kewenangan Mahkamah Pidana Internasional Untuk Mengadili Pelaku Kejahatanpelanggaran Ham Berat Dalam Suatu Negara Tanpa Adanya Permintaan Dari Negara Tuan Rumah". Jurnal Ilmiah.

[17] Obura, K. (2015). "The Security Council And The International Criminal Court: When Can The Security Council Defer A Case". Strathmore Law Journal.

[18] Suwardi, S. S. (2003). "Beberapa Catatan Mahkamah Pidana Internasional (International Criminal Court) Dalam Kaitannya Dengan Perserikatan BangsaBangsa (PBB)". Hukum dan Pembangunan, 33 (4).

[19] Sefriani, (2009). "Kewenangan Dewan Keamanan Menghentikan Yurisdiksi ICC : Studi Kasus Resolusi Dewan Keamanan Nomor 1497 Tahun 2003”, Jurnal Hukum, $16(1)$.

\section{Skripsi, Tesis, Disertasi dan Lain-Lain}

[20] Anditya, A. W. (2017). Implikasi Hak Referral Dan Hak Deferral Dewan Keamanan Perserikatan Bangsa-Bangsa Terhadap Penegakan Hukum Pidana Internasional Oleh Mahkamah Pidana Internasional, Tesis, Universitas Gadjah Mada.

\section{Online/World Wide Web}

[21] Matamata Politik. (2018). Luka PBB Laporkan Jumlah Palestina Yang Terus Bertambah Di Pawai Gaza. Retrieved from https://www.matamatapolitik.com/40mati-5-511-lukaluka-pbb-laporkan-jumlah-korban. 